\title{
Genetic Change Within Populations of Phytophthora infestans in the United States and Canada During 1994 to 1996: Role of Migration and Recombination
}

\author{
Stephen B. Goodwin, Christine D. Smart, Robert W. Sandrock, Kenneth L. Deahl, Zamir K. Punja, and William E. Fry
}

First author: USDA, Agricultural Research Service, Crop Production and Pest Control Research Unit, Department of Botany and Plant Pathology, 1155 Lilly Hall, Purdue University, West Lafayette, IN 47907-1155; second, third, and sixth authors: Department of Plant Pathology, 334 Plant Science Building, Cornell University, Ithaca, NY 14853; fourth author: USDA, Agricultural Research Service, Vegetable Laboratory, Beltsville, MD 20705; and fifth author: Centre for Pest Management, Department of Biological Sciences, Simon Fraser University, Burnaby, British Columbia V5A 1S6, Canada.

Accepted for publication 28 May 1998.

\begin{abstract}
Goodwin, S. B., Smart, C. D., Sandrock, R. W., Deahl, K. L., Punja, Z. K., and Fry, W. E. 1998. Genetic change within populations of Phytophthora infestans in the United States and Canada during 1994 to 1996: Role of migration and recombination. Phytopathology 88:939-949.

Dramatic changes occurred within populations of Phytophthora infestans in the United States and Canada from 1994 through 1996. Occurrence of the US-8 genotype, detected rarely during 1992 and 1993, increased rapidly and predominated in most regions during 1994 through 1996. US-7, which infected both potato and tomato and made up almost $50 \%$ of the sample during 1993, was detected only rarely among 330 isolates from the United States analyzed during 1994. It was not detected at all in more limited samples from 1996. Thus, ability to infect both potato and tomato apparently did not increase the fitness of this genotype relative to US- 8 , as predicted previously. US-1, the previously dominant genotype throughout the United States and Canada, made up $8 \%$ or less of the samples ana-

tion probably were limited, because the A1 and A2 mating types usually were separated geographically. The high sensitivity of the US-1 genotype to the fungicide metalaxyl also could have reduced opportunities for contact between the mating types in fields where this compound was applied. The previous correlation between metalaxyl sensitivity and genotype was confirmed and extended to a new genotype, US-17: all US-1 isolates tested were sensitive; all isolates of the US-7, US-8, and US-17 genotypes tested to date have been resistant. Isolates of $P$. capsici and P. erythroseptica, two other species often found on tomato and potato, could be easily distinguished from each other and from $P$. infestans using a simple allozyme assay for the enzyme glucose-6-phosphate isomerase. This technique could be useful for rapid identification of species, in addition to genotype of $P$. infestans. It generally was not possible to predict which genotypes would be present in a location from 1 year to the next. Long-distance movement of US-8 in seed tubers was documented, and this was probably the primary means for the rapid spread of this genotype from 1993 through 1996.
\end{abstract} lyzed during 1994 through 1996. A few additional genotypes were detected, which could indicate the beginnings of sexual reproduction of $P$. infestans within the United States and Canada. However, clonal reproduction still predominated in all locations sampled; opportunities for sexual reproduc-
Additional keywords: DNA fingerprinting, fungicide resistance, late blight, migration, population genetics.
Late blight of potato and tomato, caused by Phytophthora infestans (Mont.) de Bary, reemerged as a serious disease in the United States and Canada during the early 1990s (15). The disease had not been particularly problematic during the 1970s and 1980s. Disease-control failures caused by strains resistant to the fungicide metalaxyl were first noted in the western United States during 1990 (4). Problems worsened during 1992 and, by the end of 1993, epidemics had been reported throughout the United States and western Canada $(5,8,25)$, usually caused by metalaxyl-resistant strains $(8,25)$. Severe epidemics continued in the eastern United States during 1994 and shifted to the western states during 1995 (15). The economic cost of late blight to U.S. potato and tomato growers during this period was estimated at more than $\$ 230$ million $(14,26)$.

The increased disease severity coincided with major genetic changes in populations of $P$. infestans throughout the United States and western Canada $(6,17,23)$. Allozyme and DNA fingerprint analyses revealed that most of the problems during 1992 and 1993

Corresponding author: S. B. Goodwin; E-mail address: goodwin@btny.purdue.edu

Publication no. P-1998-0714-01R

This article is in the public domain and not copyrightable. It may be freely reprinted with customary crediting of the source. The American Phytopathological Society, 1998. were caused primarily by two new genotypes (US-7 and US-8) that probably were introduced from northwestern Mexico during or shortly before $1992(15,16,23)$. These genotypes were A2 mating type, resistant to metalaxyl (25), and highly pathogenic $(24,27,29$, 30 ), which undoubtedly exacerbated the severity of the 1990s' epidemics $(15,24)$.

US-7 was the predominant genotype during 1993 (23), both numerically (55\% of all isolates analyzed) and geographically. It was found first in New York, Tennessee, and North Carolina during 1992, but was identified in 10 states during 1993 (23). This genotype is highly pathogenic to tomato in addition to potato $(24,30)$, which may have given it a selective advantage. By contrast, during 1993, US-8 was found only in one county in Maine (23).

The rapid spread of US-7 and the persistence of the A1 US-1 genotype meant that both mating types were widely distributed during 1993 (5,23). However, opportunities for sexual reproduction probably were limited. Among hundreds of fields sampled, both mating types were found together only in a small number of fields in Florida (5,23), Texas (5), and British Columbia, Canada (23). More intensive sampling revealed that A1 and A2 coexisted in an additional 23 fields in British Columbia during 1993, in seven fields in New Brunswick during 1994 (2), and in one of six intensively sampled fields in Oregon and Washington during 1995 (P. B. Hamm, personal communication). However, probable sex- 
ual recombinants were found only in British Columbia during 1992 (23) and in the Columbia Basin of Oregon and Washington during 1993 (33). In Florida, Texas, and New Brunswick, coexistence of both mating types probably was too recent for the products of sexual reproduction to be detectable. Thus, as of 1993, although both mating types were present, there was only limited evidence of sexual reproduction in the Pacific Northwest and none in other areas of the United States.

The purpose of this study was to analyze populations of $P$. infestans during its recent resurgence in the United States to (i) identify which genotypes caused the devastating epidemics during 1994 through 1996; (ii) determine whether any additional migrations from Mexico or Europe had occurred since the last survey during 1993; and (iii) search for isolates with recombinant genotypes to determine whether sexual recombination was occurring more frequently in the United States. A secondary goal was to test whether genotype frequencies remained stable from year to year and thus could be used to predict the genetic composition of future populations. A final goal was to determine whether other species of Phytophthora that infect potato or tomato could be identified using the rapid cellulose-acetate electrophoresis system (21) used for identifying genotypes of $P$. infestans.

\section{MATERIALS AND METHODS}

Sources of isolates. Isolates of $P$. infestans were obtained from potato, tomato, or hairy nightshade (Solanum sarrachoides Sendtner) plants infected during calendar years 1994 through 1996. In addition, during 1993, 109 isolates from potato also were analyzed. Most isolates were obtained from infected leaf, stem, fruit, or tuber tissue sent to Cornell University (Ithaca, NY) or the Vegetable Laboratory (Beltsville, MD) from cooperators throughout the United States. Some tissue was collected by laboratory personnel directly, and other isolates were received as axenic cultures. In total, 556 isolates were obtained from at least 220 fields including 455 isolates from potato (185 fields), 95 from tomato (32 fields), and six from hairy nightshade ( 3 fields). Fields were from commercial growers (some organic), home gardens, volunteer potatoes, or research plots and were separated spatially from other fields. Isolates were obtained by transferring fresh sporangia to agar media (usually rye $B$ [1]) using a small agar block on the tip of a spatula as described previously $(5,23)$. Tissue that was not sporulating was placed in a petri dish with a small amount of moistened filter paper at $18^{\circ} \mathrm{C}$ for 1 to 4 days to induce sufficient sporulation for isolation. For tissue that was beginning to decay, P. infestans was rescued by placing a fresh tuber slice (potato cv. Norchip, approximately $0.75 \mathrm{~cm}$ thick) on top of the infected tissue in a $9-\mathrm{cm}$ petri plate. Usually, $P$. infestans would grow through the tuber slice and sporulate within 2 to 6 days. Clean-up medium (22), pea (17), and $10 \% \mathrm{~V}-8$ juice (34) agars were occasionally used to make isolations. After isolation, cultures were grown on rye A agar (1). A subset of the isolates was stored cryogenically at $-135^{\circ} \mathrm{C}$.

In addition to $P$. infestans, isolates of two other Phytophthora species were analyzed during 1994. Four isolates of $P$. capsici were obtained from infected tomato fruits from a metalaxyl (Ridomil)sprayed field near Sacramento, CA, and 21 isolates of $P$. erythroseptica were obtained from potato tubers in New York and Maine (20). The total number of isolates of all species analyzed was 581 .

Isolate characterization. All isolates collected during 1993 and 1994 and some of those from 1996 were analyzed for mating type and for genotype at the two allozyme loci glucose-6-phosphate isomerase (Gpi) and peptidase (Pep). Isolates from 1995 and some of those from 1996 were analyzed for mating type and $G p i$ genotype; others were analyzed for Gpi genotype alone at the Cornell University Diagnostic Laboratory. Mating type was determined by pairing each isolate with known A1 and A2 testers (17). Each tester was placed in the center of a $9-\mathrm{cm}$ petri plate, and three unknowns were placed equidistant around the edges. Thus, only two plates were required to test three isolates. Ambiguous reactions were repeated as necessary to obtain clear results.

Tissue for allozyme and DNA fingerprint analyses was grown as described previously $(17,21)$. Allozyme genotypes were deter-

TABLE 1. Characteristics and frequencies of genotypes of Phytophthora infestans detected among 556 isolates analyzed during 1993 to 1996 from the United States and Canada and a few isolates each of $P$. capsici and P. erythroseptica analyzed during 1994

\begin{tabular}{|c|c|c|c|c|c|c|c|c|}
\hline \multirow[b]{2}{*}{ Genotype } & \multirow{2}{*}{$\begin{array}{l}\text { Mating } \\
\text { type }\end{array}$} & \multicolumn{2}{|c|}{ Allozyme genotype } & \multirow{2}{*}{$\begin{array}{l}\text { Metalaxyl } \\
\text { response }^{\mathrm{c}}\end{array}$} & \multicolumn{4}{|c|}{ Frequency of detection during } \\
\hline & & $G p i^{\mathrm{a}}$ & $P e p^{\mathrm{b}}$ & & $1993^{d}$ & $1994^{\mathrm{e}}$ & $1995^{f}$ & $1996^{\mathrm{g}}$ \\
\hline \multicolumn{9}{|l|}{ P. infestans } \\
\hline US-1 & A1 & $86 / 100$ & $92 / 100$ & $\mathrm{~S}$ & 7.4 & 7.6 & 3.1 & 7.7 \\
\hline US-6 & A1 & $100 / 100$ & $92 / 100$ & $\mathrm{~S}$ & 11.9 & 1.2 & 0.0 & 0.0 \\
\hline US-6.5 & A1 & $100 / 100$ & $92 / 100$ & $\mathrm{R}$ & 0.9 & 0.0 & 0.0 & 0.0 \\
\hline US-7 & $\mathrm{A} 2$ & $100 / 111$ & $100 / 100$ & $\mathrm{R}$ & 37.6 & 5.8 & 43.0 & 0.0 \\
\hline US-8 & $\mathrm{A} 2$ & $100 / 111 / 122$ & $100 / 100$ & $\mathrm{R}$ & 5.5 & 77.2 & 47.7 & 69.2 \\
\hline US-11 & A1 & $100 / 100 / 111$ & $100 / 100$ & $\mathrm{R}$ & 0.0 & 6.7 & 6.2 & 0.0 \\
\hline US-12 & A1 & $100 / 111$ & $92 / 100$ & $\mathrm{R}$ & 0.0 & 0.3 & 0.0 & 0.0 \\
\hline US-13 & A2 & $100 / 100$ & $100 / 100$ & $\mathrm{R}$ & 0.0 & 0.9 & 0.0 & 0.0 \\
\hline US-14 & A2 & $100 / 122$ & $100 / 100$ & $\mathrm{R}$ & 0.0 & 0.3 & 0.0 & 0.0 \\
\hline US-16 & A1 & $100 / 111$ & $100 / 100$ & $\mathrm{R}$ & 0.0 & 0.0 & 0.0 & 7.7 \\
\hline US-17 & A1 & $100 / 122$ & $100 / 100$ & $\mathrm{R}$ & 0.0 & 0.0 & 0.0 & 15.4 \\
\hline BC-1/US- $7^{\mathrm{h}}$ & $\mathrm{A} 2$ & $100 / 111$ & $100 / 100$ & $\mathrm{I} / \mathrm{R}$ & 22.9 & 0.0 & 0.0 & 0.0 \\
\hline BC-1 & $\mathrm{A} 2$ & $100 / 111$ & $100 / 100$ & I & 11.9 & 0.0 & 0.0 & 0.0 \\
\hline CA-8 & A1 & $100 / 111 / 111$ & $100 / 100$ & $\ldots{ }^{\mathrm{i}}$ & 1.9 & 0.0 & 0.0 & 0.0 \\
\hline \multicolumn{9}{|l|}{ P. capsici } \\
\hline CAP-1 & $\ldots$ & $106 / 106$ & $94 / 94$ & $\mathrm{~S}$ & $\ldots$ & 1.0 & $\ldots$ & $\ldots$ \\
\hline \multicolumn{9}{|l|}{ P. erythroseptica } \\
\hline ERY-1 & $\mathrm{SF}^{\mathrm{j}}$ & $91 / 91$ & $\ldots$ & $\mathrm{S}, \mathrm{I}, \mathrm{R}^{\mathrm{k}}$ & $\ldots$ & 1.0 & $\ldots$ & $\ldots$ \\
\hline
\end{tabular}

a Glucose-6-phosphate isomerase.

b Peptidase.

${ }^{c} \mathrm{~S}=$ sensitive, $\mathrm{R}=$ resistant, and $\mathrm{I}=$ intermediate. No intermediate isolates were tested in this study, but BC-1 isolates were scored intermediate previously (25).

d $N=109$.

e $N=330$.

f $N=65$.

g $N=52$.

h These isolates probably were either BC-1 or US-7.

i Not determined.

j Self fertile.

${ }^{\mathrm{k}}$ Reported previously (20). 
mined by starch gel analysis (17) or with cellulose acetate (21). During 1996, Gpi genotype often was determined by analyzing mycelia or sporangia plucked or washed directly from infected tissue (21). Procedures for DNA fingerprinting were as described previously (19). Because of the predominance of the US- 8 genotype (discussed in Results) and the high ability of allozyme analysis to identify recombinant genotypes in these populations, only a low number of isolates was scored for DNA fingerprint.

Metalaxyl sensitivity was determined for a small subset of the isolates using amended-agar or floating leaf-disc assays as described previously $(25,32)$. Isolates were grown on rye B medium containing 0,5 , or $100 \mu \mathrm{g}$ of metalaxyl per $\mathrm{ml}$, and colony diameters were measured after 6 to 9 days. Some isolates were tested only on 0 and $100 \mu \mathrm{g}$ of metalaxyl per ml. For the leaf-disc assays, only 0 and $5 \mu \mathrm{g}$ of metalaxyl per $\mathrm{ml}$ were used, and the assays were scored after 5 to 8 days. Isolates of $P$. capsici were scored on amended-agar assays after 3 days. Isolates that grew more than $50 \%$ of the control on $5 \mu \mathrm{g}$ of metalaxyl per ml were considered resistant; all others were scored sensitive.

\section{RESULTS}

Thirteen genotypes of $P$. infestans were found in the total sample of 556 isolates analyzed during 1993 through 1996 (Table 1). Genotype frequencies varied widely from year to year, and only two genotypes (US-1 and US-8) were detected during all 4 years (Table 1).

Genotype identification: 1993. Analyses of 181 isolates from 1993 were reported previously (23). The 109 additional isolates analyzed here were mostly from Texas and British Columbia and were of particular interest because these were among only five locations where both mating types have been found in the same field $(5,23)$. Analysis of 38 isolates from Texas revealed that 12 were US-6 (A1 mating type) and 26 were US-7 (A2 mating type) (Table 2). Among 58 isolates from Canada, one (from Alberta) was US-1, one (from British Columbia) was US-6, one was US-6.5 (confirmed by DNA fingerprint analysis), and two had a new genotype, CA-8 (Table 2). The remaining 54 isolates were A2 mating type and $G p i$ 100/111, Pep 100/100, which corresponds to the US-7 and BC-1 genotypes. DNA fingerprint analysis of 14 of these isolates revealed that 4 were BC-1 and 10 were US-7. Identities of five additional US-7 and nine BC-1 isolates were confirmed by random amplified polymorphic DNA analysis (Z. K. Punja, unpublished data). The remaining isolates were not analyzed for DNA fingerprint, but were assumed to represent either US-7 or BC-1.

The remaining 1993 isolates were from seed tubers grown during 1993 that were collected and analyzed during early 1994. Two isolates, collected from Maine seed shipped to Florida during late 1993, had the US-8 genotype, as did four other isolates from Maine seed sent to New York during April 1994. Seven isolates, from North Dakota seed shipped into New York during April 1994, were US-1 (Table 2).

Genotype identification: 1994. Among the 330 isolates of $P$. infestans analyzed during 1994, 52 (16\%) were A1 and the rest were A2. No self-fertile isolates were identified. The A1 and A2 mating types were found together only in 1 among the 134 fields sampled (Table 3); one A1 isolate was found in the same field as a US-8 genotype. Unfortunately, the A1 isolate from that field was lost before its genotype could be determined. Among the remaining isolates, eight genotypes were identified, only four of which were detected commonly (frequency $>5 \%$ ) (Table 1). By far the most commonly detected genotype was US-8, found on potato, tomato, and hairy nightshade (Table 3 ) throughout the United States and in New Brunswick, Canada. Two US-8 isolates were obtained from hairy nightshade growing in a cabbage field four miles from the nearest field of potato. US-8 was detected in 12 counties in New York during 1994 (Table 3), even though it was not detected at all in New York during 1993 (23).
TABLE 2. Sampling information and genotype for 109 isolates of Phytophthora infestans from potato during the 1993 growing season in the United States and Canada

\begin{tabular}{|c|c|c|c|c|c|c|}
\hline $\begin{array}{l}\text { State or } \\
\text { province }\end{array}$ & $\begin{array}{l}\text { County } \\
\text { or city }\end{array}$ & $\begin{array}{c}\text { Host } \\
\text { cultivar }\end{array}$ & $\begin{array}{c}\text { Month } \\
\text { collected }\end{array}$ & $\begin{array}{l}\text { No. of } \\
\text { fields }\end{array}$ & $\begin{array}{l}\text { No. of } \\
\text { isolates }\end{array}$ & Genotype(s) \\
\hline Alberta & Brooks & $\begin{array}{l}\text { Russet } \\
\text { Burbank }\end{array}$ & August & 1 & 1 & US-1 \\
\hline \multicolumn{7}{|l|}{ British } \\
\hline \multirow[t]{47}{*}{ Columbia } & Chilliwack & $\ldots^{\mathrm{a}}$ & July & $\ldots$ & 3 & BC-1/US-7 ${ }^{b}$ \\
\hline & & & & & 1 & US-6.5 \\
\hline & & & & & 2 & US-7 \\
\hline & Cloverdale & Eramosa & June & 1 & 1 & BC-1/US-7 ${ }^{b}$ \\
\hline & & Norchip & July & 1 & 1 & BC-1/US-7 ${ }^{b}$ \\
\hline & & Norkotah & July & 1 & 1 & BC-1/US-7b \\
\hline & & Norland & July & 1 & 4 & BC-1/US-7 ${ }^{b}$ \\
\hline & & Burbank & June & 1 & 1 & BC-1 \\
\hline & & & & & 1 & US-7 \\
\hline & & & July & 3 & 1 & BC-1 \\
\hline & & & & & 2 & US-7 \\
\hline & & & & & 1 & BC-1/US-7 ${ }^{b}$ \\
\hline & & & August & 1 & 1 & US-7 \\
\hline & & & September & 1 & 1 & US-7 \\
\hline & & Russet & & & & \\
\hline & & Norkotah & June & 2 & 2 & BC-1 \\
\hline & & & & & 1 & US-6 \\
\hline & & & & & 2 & US-7 \\
\hline & & & July & 2 & 1 & BC-1/US-7 ${ }^{b}$ \\
\hline & & & & & 2 & US-7 \\
\hline & & Warba & June & 2 & 1 & BC-1/US-7 ${ }^{b}$ \\
\hline & & & & & 2 & US-7 \\
\hline & & Yukon Gold & July & 1 & 1 & BC-1/US-7b \\
\hline & & $\ldots$ & July & 1 & 1 & BC-1/US-7 ${ }^{b}$ \\
\hline & Delta & Norchip & June & 1 & 1 & US-7 \\
\hline & & Red LaSoda & June & 2 & 1 & BC-1/US- $7^{b}$ \\
\hline & & & & & 3 & BC-1 \\
\hline & & Russet & & & & \\
\hline & & Norkotah & June & 1 & 2 & BC-1/US-7b \\
\hline & & & & & 1 & BC-1 \\
\hline & & & & & 1 & CA-8 \\
\hline & & & August & 1 & 1 & BC-1/US-7b \\
\hline & & Sunrise & July & 1 & 1 & BC-1 \\
\hline & & Warba & July & 1 & 1 & BC-1/US- $7^{b}$ \\
\hline & Ladner & Warba & July & 1 & 2 & BC-1/US-7b \\
\hline & Okanagan & Nooksack & September & 1 & 1 & BC-1/US-7 ${ }^{b}$ \\
\hline & & Russet & & & & \\
\hline & & Burbank & September & 1 & 1 & BC-1 \\
\hline & & & & 1 & 1 & US-7 \\
\hline & & Russet & & & & \\
\hline & & Norkotah & August & 1 & 1 & BC-1/US-7b \\
\hline & Vancouver & Russet & & & & \\
\hline & Island & Burbank & September & 1 & 1 & $\mathrm{BC}-1$ \\
\hline & & Russet & & & & \\
\hline & & Norkotah & August & 1 & 1 & CA-8 \\
\hline & & Yukon Gold & August & 1 & 2 & BC-1 \\
\hline & & $\ldots$ & August & 1 & 1 & BC-1/US-7b \\
\hline \multirow[t]{4}{*}{ Maine } & Aroostook & $\ldots$ & January & 1 & 2 & US-8 \\
\hline & & & $1994^{c}$ & & & \\
\hline & & Norwis & April $1994^{\mathrm{d}}$ & 1 & 1 & US-8 \\
\hline & & Snowden & April $1994^{\mathrm{d}}$ & 1 & 3 & US-8 \\
\hline \multicolumn{7}{|l|}{ North } \\
\hline Dakota & $\ldots$ & FL 1533 & April $1994^{\mathrm{d}}$ & $\ldots$ & 7 & US-1 \\
\hline \multirow[t]{3}{*}{ Texas } & Cameron & FL 1533 & Jan.-March & $\ldots$ & 13 & US-7 \\
\hline & Hidalgo & FL 1533 & Jan.-March & $\ldots$ & 12 & US-6 \\
\hline & & & Jan.-March & $\ldots$ & 13 & US-7 \\
\hline
\end{tabular}

a Not known.

b These isolates were A2 mating type and glucose-6-phosphate isomerase $100 / 111$, peptidase 100/100. They were not tested for DNA fingerprint, but were assumed to be either BC-1 or US-7.

c These were assayed from seed tubers sent to Florida. Even though they were collected during 1994, they reflected genotypes present in the field during the 1993 growing season. The remainder of the seed was planted.

$\mathrm{d}$ These were assayed from seed tubers sent to New York. Even though they were collected during 1994, they reflected genotypes present in the field during the 1993 growing season. 
The second most commonly detected genotype (8\%) during 1994 was US-1 (Table 1). This genotype was found only in seed tubers from Nebraska and in potato fields in single counties in six states (Michigan, North Carolina, North Dakota, Oregon, Washington, and Wisconsin). Many New York potato growers planted infected seed after we determined that it contained US-1, yet US-1 was not recovered from the field in New York during 1994.

US-11 was the third most commonly detected genotype, making up $7 \%$ of the total sample (Table 1). The US-11 genotype was found in the Mt. Vernon variety trials in Skagit County, WA. This genotype had an unbalanced heterozygote pattern for the Gpi locus, with three bands in an approximately 4:4:1 ratio of intensities (Fig. 1). Thus, it probably has two copies of the 100 allele and was scored Gpi 100/100/111 (Table 1).

The only other widespread genotype was US-7 (6\% of the total sample). This genotype was found only on tomato in five states, most of which were in the south (Table 3 ).

US-6, common during the early 1990s (17), was found only in two fields in Umatilla County, OR, during 1994 (Table 3) and made up only $1 \%$ of the sample that year (Table 1 ).
The remaining three genotypes were rare (less than $1 \%$ each) (Table 1) and were found only in our more extensive samples from New York (Table 3). One US-12 isolate was obtained from a tomato fruit from Maclean, NY. This genotype was A1 mating type and had a Gpi genotype like US-7, but a Pep genotype like US-1 or US-6. The US-13 genotype was found in two isolates from a commercial tomato field in Dryden, NY. These isolates were A2 mating type and 100/100 for Gpi and Pep. A third isolate from the same field also was A2 mating type, but was lost before its genotype could be determined. The final genotype, US-14, was found in a potato field that also had US-8. It differed from US-8 only in Gpi genotype: $100 / 122$ for US-14 versus $100 / 111 / 122$ for US-8.

Four isolates of $P$. capsici were tested during 1994, and all had the same genotype: Gpi 106/106, Pep 94/94. All 21 isolates of $P$. erythroseptica were Gpi $91 / 91$ (Table 3). We could not obtain useful resolution of Pep genotypes of $P$. erythroseptica. Because the isozyme genotypes of $P$. capsici and $P$. erythroseptica were different from each other and from all of the $P$. infestans genotypes, it was easy to distinguish all three species on the basis of Gpi genotype alone.

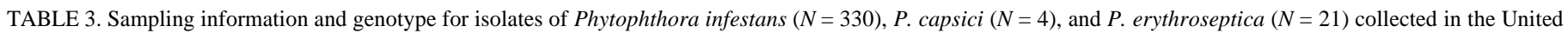
States and Canada during 1994

\begin{tabular}{|c|c|c|c|c|c|c|c|c|c|c|c|c|c|}
\hline $\begin{array}{l}\text { State or } \\
\text { province }\end{array}$ & County & Host cultivar & $\begin{array}{c}\text { Month } \\
\text { collected }\end{array}$ & $\begin{array}{l}\text { No. of } \\
\text { fields }\end{array}$ & $\begin{array}{l}\text { No. of } \\
\text { isolates }\end{array}$ & Genotype & $\begin{array}{l}\text { State or } \\
\text { province }\end{array}$ & County & Host cultivar & $\begin{array}{l}\text { Month } \\
\text { collected }\end{array}$ & $\begin{array}{l}\text { No. of } \\
\text { fields }\end{array}$ & $\begin{array}{l}\text { No. of } \\
\text { isolates }\end{array}$ & Genotype \\
\hline \multicolumn{2}{|c|}{ Isolates from potato } & & & 116 & 277 & & N. Dakota & Walsh & FL 1533 & August & 1 & 1 & US-1 \\
\hline \multirow[t]{2}{*}{ Florida } & Dade & $\ldots^{\mathrm{a}}$ & January & 8 & 12 & US-8 & Oregon & Umatilla & Russet Burbank & July & 2 & 4 & US-6 \\
\hline & St. Johns & $\ldots$ & July & 4 & 5 & US-8 & & & & August & 1 & 1 & US-1 \\
\hline Georgia & Miller & Atlantic & May & 2 & 6 & US-8 & & & & & 1 & 1 & US-8 \\
\hline \multirow[t]{4}{*}{ Maine } & Aroostook & FL 1533 & July & 2 & 2 & US-8 & & & Shepody & July & 1 & 2 & US-8 \\
\hline & & Gold Rush & August & 1 & 1 & US-8 & & Washington & $\ldots$ & September & 1 & 4 & US-8 \\
\hline & & Russet Burbank & August & 1 & 1 & US-8 & Pennsylvania & Centre & Katahdin & September & 1 & 2 & US-8 \\
\hline & & St. John & August & 1 & 2 & US-8 & & Erie & Red LaSoda & September & 1 & 3 & US-8 \\
\hline \multirow[t]{8}{*}{ Michigan } & Isabella & $\ldots$ & August & 1 & 3 & US-8 & & Potter & Atlantic & August & 1 & 1 & US-8 \\
\hline & Kent & $\ldots$ & August & 1 & 3 & US-8 & & & Snowden & August & 1 & 3 & US-8 \\
\hline & Mecosta & $\ldots$ & August & 2 & 7 & US-8 & & & Superior & August & 1 & 3 & US-8 \\
\hline & Montcalm & $\ldots$ & August & 13 & 49 & US-8 & Washington & Franklin & Ranger Russet & June & 1 & 2 & US-1 \\
\hline & & $\ldots$ & October & 4 & 5 & US-8 & & & & July & 2 & 4 & US-1 \\
\hline & Presque Isle & $\ldots$ & October & 3 & 7 & US-1 & & & Russet Burbank & August & 1 & 1 & US-1 \\
\hline & & Onaway & October & 1 & 2 & US-1 & & Skagit & Halite & August & 1 & 1 & US-11 \\
\hline & Saginaw & $\ldots$ & November & 1 & 4 & US-8 & & & Kennebec & August & 1 & 1 & US-11 \\
\hline Nebraska & Dawes & Red LaSoda ${ }^{\mathrm{b}}$ & October & 1 & 3 & US-1 & & & Norkota & August & 1 & 1 & US-11 \\
\hline \multirow{2}{*}{$\mathrm{NB}^{\mathrm{c}}$} & Carleton & Gold Rush & August & 1 & 3 & US-8 & & & Ranger Russet & August & 1 & 1 & US-11 \\
\hline & & Snowden & August & 1 & 4 & US-8 & & & White Rose & August & 2 & 10 & US-11 \\
\hline \multirow[t]{22}{*}{ New York } & Cayuga & $\ldots$ & September & 1 & 2 & US-8 & & & $\ldots$ & August & 2 & 7 & US-11 \\
\hline & Chautauqua & Kennebec & September & 1 & 2 & US-8 & & $\ldots$ & $\ldots$ & August & 1 & 1 & US-11 \\
\hline & Erie & $\ldots$ & September & 1 & 1 & US-8 & W. Virginia & Preston & Elba & August & 1 & 1 & US-8 \\
\hline & Niagara & Chippewa & November & 1 & 2 & US-8 & & & Katahdin & August & 1 & 1 & US-8 \\
\hline & Oneida & $\ldots$ & August & 3 & 9 & US-8 & Wisconsin & $\ldots$ & $\ldots$ & August & $\ldots$ & 2 & US-1 \\
\hline & Ontario & Snowden & September & 1 & 6 & US-8 & Isolates from & tomato & & & 15 & 47 & \\
\hline & & $\ldots$ & October & 1 & 2 & US-8 & Florida & Manatee & $\ldots$ & April & 2 & 8 & US-7 \\
\hline & Steuben & 657 & August & 2 & 2 & US-8 & New York & Chautauqua & $\ldots$ & September & 3 & 14 & US-8 \\
\hline & & Atlantic & August & 1 & 3 & US-8 & & Genesee & $\ldots$ & September & 1 & 1 & US-8 \\
\hline & & FL 1533 & September & 1 & 1 & US-8 & & Ontario & $\ldots$ & Sept., Oct. & 2 & 6 & US-8 \\
\hline & & Monona & Sept., Oct. & 2 & 3 & US-8 & & Steuben & $\ldots$ & August & 1 & 3 & US-8 \\
\hline & & $\ldots$ & Aug.-Oct. & 14 & 34 & US-8, & & Tompkins & $\ldots$ & September & 1 & 3 & US-7 \\
\hline & & & & & 1 & US-? ${ }^{\mathrm{d}}$ & & & $\ldots$ & September & 1 & 1 & US-12 \\
\hline & & & & & 1 & US-14 & & & $\ldots$ & September & 1 & 3 & US-13 \\
\hline & Tioga & $\ldots$ & August & 1 & 5 & US-8 & S. Carolina & Charleston & $\ldots$ & June & 1 & 4 & US-7 \\
\hline & Tompkins & $\ldots$ & September & 1 & 4 & US-8 & Tennessee & Rhea & $\ldots$ & September & 1 & 3 & US-7 \\
\hline & Unknown & $\ldots$ & September & 1 & 1 & US-8 & Virginia & Giles & $\ldots$ & August & 1 & 1 & US-7 \\
\hline & Washington & $\ldots$ & September & 1 & 3 & US-8 & Isolates from & hairy nightsh & hade (Solanum sa & rrachoides) & 3 & 6 & \\
\hline & & Katahdin & October & 1 & 1 & US-8 & New York & Ontario & ... & September & 2 & 4 & US-8 \\
\hline & Wyoming & $\ldots$ & August & 1 & 3 & US-8 & & Orleans & $\ldots$ & September & 1 & 2 & US-8 \\
\hline & & Kanona & September & 1 & 1 & US-8 & Isolates of $P h$ & hytophthora co & apsici & & & & \\
\hline & & Monona & September & 1 & 3 & US-8 & California & Sacramento & $\ldots$ & September & 1 & 4 & CAP-1 \\
\hline \multirow[t]{3}{*}{ N. Carolina } & Camden & $\ldots$ & May & 1 & 2 & US-1 & Isolates of $P h$ & hytophthora en & rythroseptica & & 8 & 21 & \\
\hline & Pamlico & $\ldots$ & June & 1 & 1 & US-8 & Maine & Aroostook & $\ldots$ & $\ldots$ & 1 & 1 & ERY-1 \\
\hline & Washington & $\ldots$ & June & 1 & 4 & US-8 & New York & Orleans & $\ldots$ & October & 1 & 3 & ERY-1 \\
\hline N. Dakota & Pembina & FL 1533 & August & 1 & 3 & US-8 & & Suffolk & Norwis & November & 6 & 17 & ERY-1 \\
\hline
\end{tabular}

a Not known.

b Isolated from seed tubers sent to Florida.

c New Brunswick.

${ }^{\mathrm{d}}$ One A1 isolate was found in a field with a US-8 isolate, but was lost before its genotype could be determined.

e One US-14 isolate was found in a field with a US-8 isolate. 
DNA fingerprint analysis of 15 isolates confirmed that 10 with mating type and allozyme genotype like US-8 (from Pennsylvania, Maine, and four counties in New York) plus the US-14 isolate had the characteristic US-8 fingerprint pattern. Representative isolates of the US-1, US-11 (two isolates), and US-12 genotypes also were tested for DNA fingerprint (Fig. 2).

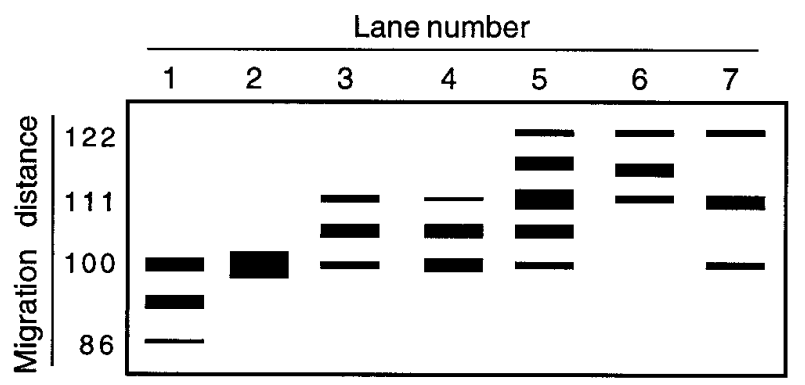

Fig. 1. Schematic gel-banding patterns at the glucose-6-phosphate isomerase (Gpi) locus for the most commonly detected genotypes of Phytophthora infestans in the United States and Canada. The Gpi genotypes and associated clonal lineages of $P$. infestans are as follows: lane 1, Gpi 86/100/100, characteristic of the US-1 clonal lineage; lane 2, Gpi 100/100, US-6; lane 3, Gpi 100/111, US-7 and BC-1; lane 4, Gpi 100/100/111, US-11; lane 5, Gpi 100/111/122, US-8; lane 6, Gpi 111/122, US-10; and lane 7, Gpi 100/122, US-17. Note the unbalanced heterozygote patterns in lanes 1 and 4 , most likely caused by two copies of the Gpi 100 allele. Unbalanced heterozygotes are characteristic of the US-1 and US-11 genotypes and have three bands in an approximately 1:4:4 ratio of intensities ( $4: 4: 1$ for US-11). Compare these with the balanced heterozygote patterns in lanes 3,6 , and 7 , in which the three bands are in an approximately 1:2:1 ratio of intensities.

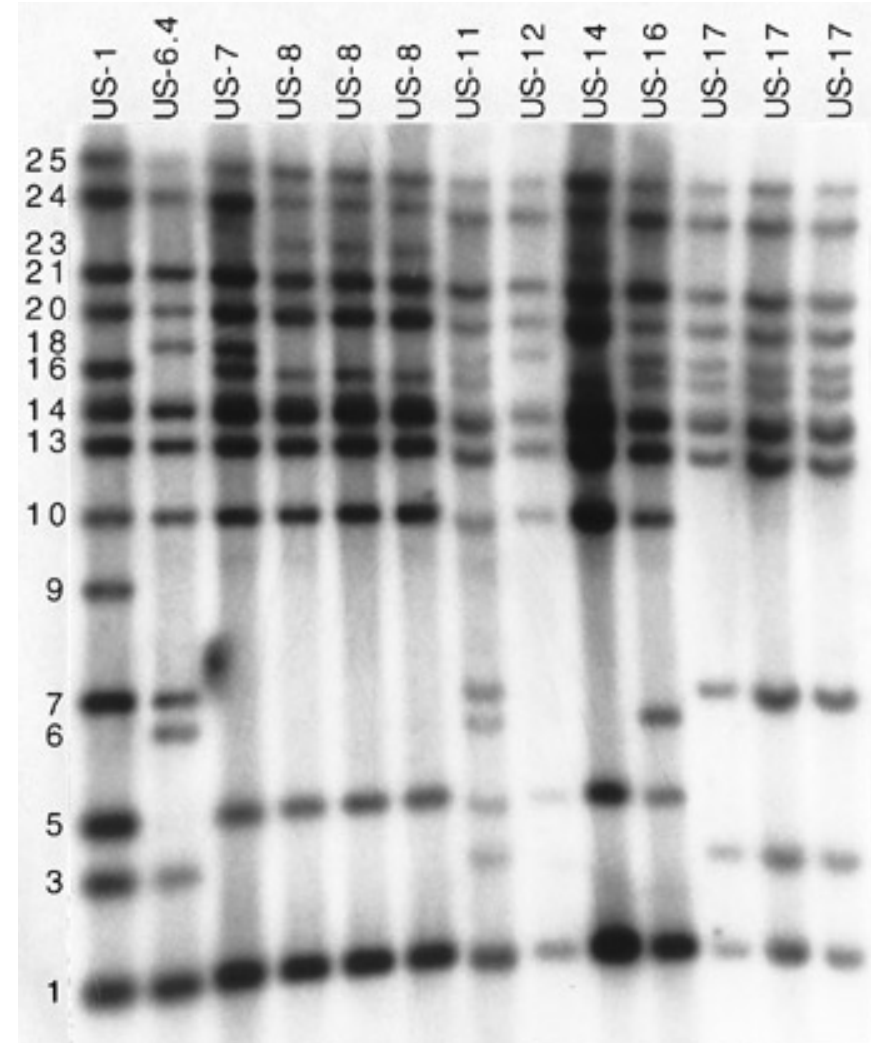

Fig. 2. RG57 fingerprint patterns of nine genotypes of Phytophthora infestans detected in the United States or Canada during 1994 through 1996. Genotype names are indicated above each lane. RG57 fingerprint band numbers are indicated on the left. US-14 is identical to US-8 and is probably a somatic variant. US-11, US-12, US-16, and US-17 are probably recombinants between US-1 or US-6 (A1 mating type) and US-7 or US-8 (A2 mating type). Locations represented by each genotype are as follows: US-1, Nebraska; US-6.4, Washington; US-8, US-12, and US-14, New York; US-16, Oregon; and US-17, Alabama, New Jersey, and New York.
Genotype identification: 1995. A similar pattern occurred during 1995 and 1996. Most isolates collected during 1995 were US-8, but US-7 isolates were found in Alaska, California, Florida, and New Jersey (Table 4). The US-11 genotype was isolated from tomato in California and New York (Table 4). US-1 was found in Michigan and Texas. During 1995 and 1996, multilocus genotype often was inferred from Gpi genotype alone, so the numbers of genotypes reported here may be underestimates. The genotypes of 12 isolates were confirmed by DNA fingerprinting including seven that were US-7 (from Alaska and California), one that was US-8 (from New York), and four that were US-11 (from California and New York).

Genotype identification: 1996. The vast majority of the isolates tested during 1996 were US-8, including isolates from Alabama, Maine, and 14 counties in New York (Table 5). US-1 was isolated from potato and tomato in Schoharie and Schenectady counties, NY, respectively (adjacent counties in eastern New York). Two unusual genotypes were found on tomato: US-16 in California and US-17 in Alabama, Florida, New Jersey, and New York (Table 5). DNA fingerprint analysis confirmed the genotype of one US-16 and seven US-17 isolates (representing all four states where this genotype was found).

Changes in genotype frequencies over time. To test whether the US-1 genotype was being replaced, frequencies of the four most commonly detected genotypes in the United States and Canada during 1979 to 1996 were calculated from data published previously $(17,23)$ and this study. Analysis of the combined data set of 1,112 isolates revealed a decline in detection frequency of the US-1 genotype (Table 6). US-1 made up more than $60 \%$ of the isolates collected during 1979 to 1987 , but declined to less than $10 \%$ during 1994 through 1996. US-6 showed a rapid increase in frequency during 1987 to 1991 , followed by a rapid decrease to less than $2 \%$ of the isolates collected during 1994 . It was not detected in our more limited samples during 1995 and 1996. US-7 peaked during 1993, declined during 1994, rebounded slightly during 1995, but was not detected during 1996. Most of the US-7

TABLE 4. Sampling information and genotype for 65 isolates of Phytophthora infestans collected in the United States during 1995

\begin{tabular}{|c|c|c|c|c|c|}
\hline State & County & $\begin{array}{l}\text { Month } \\
\text { collected }\end{array}$ & $\begin{array}{l}\text { No. of } \\
\text { fields }\end{array}$ & $\begin{array}{l}\text { No. of } \\
\text { isolates }\end{array}$ & Genotype $(\mathrm{s})^{\mathrm{a}}$ \\
\hline \multicolumn{3}{|c|}{ Isolates from potato } & 26 & 33 & \\
\hline Alaska & Matanuska-Susitna & October & 1 & 1 & US-7 \\
\hline Arizona & Maricopa & March & 1 & 1 & US-8 \\
\hline Florida & Hendry & January & 1 & 1 & US-8 \\
\hline Idaho & Canyon & July & 1 & 1 & US-8 \\
\hline Michigan & $\ldots{ }^{b}$ & $\ldots$ & 1 & 1 & US-1 \\
\hline \multirow[t]{8}{*}{ New York } & Ontario & September & 1 & 1 & US-8 \\
\hline & & October & 1 & 1 & US-8 \\
\hline & Steuben & July & 2 & 2 & US-8 \\
\hline & & August & 2 & 2 & US-8 \\
\hline & Wayne & October & 1 & 1 & US-8 \\
\hline & Wyoming & July & 1 & 3 & US-8 \\
\hline & & September & 1 & 1 & US-8 \\
\hline & Yates & August & 2 & 2 & US-8 \\
\hline \multirow[t]{4}{*}{ North Carolina } & Camden & June & 6 & 6 & US-8 \\
\hline & Currituck & June & 1 & 2 & US-8 \\
\hline & Pamlico & June & 1 & 2 & US-8 \\
\hline & Washington & June & 1 & 3 & US-8 \\
\hline Texas & Frio & March & 1 & 2 & US-1, US-8 \\
\hline \multicolumn{3}{|c|}{ Isolates from tomato } & 7 & 32 & \\
\hline \multirow[t]{2}{*}{ California } & San Luis Obispo & October & 1 & 4 & $\begin{array}{l}\text { US-7 (1), } \\
\text { US-11 (3) }\end{array}$ \\
\hline & & November & 1 & 23 & US-7 \\
\hline \multirow[t]{2}{*}{ Florida } & Hillsborough & April & 1 & 1 & US-8 \\
\hline & Manatee & April & 2 & 2 & US-7 \\
\hline New Jersey & Cumberland & July & 1 & 1 & US-7 \\
\hline New York & Erie & October & 1 & 1 & US-11 \\
\hline
\end{tabular}

${ }^{a}$ Determined from analysis of mating type, glucose-6-phosphate isomerase (Gpi) allozyme genotype, and RG57 fingerprint; for some isolates, from Gpi genotype alone. b Not known. 
isolates from 1995 came from a single field in California. Thus, rapid changes in genotype frequencies were detected over time, even from year to year.

The locations in which each genotype was detected also varied from year to year. It was not always possible to use information from 1 year to predict where a genotype would occur the next year. This was particularly evident in New York (Fig. 3). US-8 was not detected in New York during 1993, but was common and widespread during 1994. US-7 was the most common genotype in New York during 1993, but was only detected in one county during 1994. After 1994, US-8 predominated everywhere.

Metalaxyl sensitivities. Metalaxyl tests confirmed the associations between sensitivity and genotype reported previously (25) for the US-1, US-7, and US-8 genotypes (Table 7). All US-1 isolates tested were sensitive, whereas all US-7 and US-8 isolates were resistant. In addition, eight US-17 isolates were tested, and all were highly resistant (Table 7). Two US-6 isolates from Texas were highly sensitive, as reported previously for that population (5). Floating leaf-disc assays gave better discrimination between resistance and sensitivity and had a smaller variance than amended-agar assays. None of the US-1 isolates tested grew or sporulated on leaf discs floating on $5-\mu \mathrm{g} / \mathrm{ml}$ metalaxyl solution, whereas one US-1 isolate grew up to $12 \%$ of the control on $5-\mu \mathrm{g} / \mathrm{ml}$ metalaxyl-amended agar (Table 7). Similarly, US-7 and US-8 isolates grew from 64 to $106 \%$ of the control on $5-\mu \mathrm{g} / \mathrm{ml}$ metalaxylamended agar, but from 95 to $103 \%$ on floating leaf discs. One isolate, FL 318-2, was tested with both methods and grew at $71 \%$ on $5-\mu \mathrm{g} / \mathrm{ml}$ metalaxyl-amended agar, but at $95 \%$ on the floating leaf-disc test.

Both isolates of $P$. capsici tested were highly sensitive to metalaxyl (Table 7), even though they came from a field that had been sprayed with Ridomil and the grower believed they probably were resistant.

TABLE 5. Sampling information and genotype for 52 isolates of Phytophthora infestans collected in the United States during 1996

\begin{tabular}{|c|c|c|c|c|c|}
\hline State & County & $\begin{array}{c}\text { Month } \\
\text { collected }\end{array}$ & $\begin{array}{l}\text { No. of } \\
\text { fields }\end{array}$ & $\begin{array}{l}\text { No. of } \\
\text { isolates }\end{array}$ & Genotype \\
\hline \multicolumn{3}{|c|}{ Isolates from potato } & 28 & 36 & \\
\hline Alabama & Baldwin & April & 1 & 2 & US-8 \\
\hline Maine & Aroostook & July & 1 & 1 & US-8 \\
\hline \multirow[t]{18}{*}{ New York } & Clinton & August & 4 & 4 & US-8 \\
\hline & Delaware & October & 1 & 6 & US-8 \\
\hline & Franklin & August & 1 & 1 & US-8 \\
\hline & Genesee & October & 1 & 1 & US-8 \\
\hline & \multirow[t]{2}{*}{ Monroe } & August & 1 & 1 & US-8 \\
\hline & & September & 1 & 1 & US-8 \\
\hline & Ontario & September & 1 & 1 & US-8 \\
\hline & Oswego & September & 1 & 1 & US-8 \\
\hline & Schoharie & July & 1 & 3 & US-1 \\
\hline & Seneca & August & 1 & 1 & US-8 \\
\hline & St. Lawrence & September & 1 & 1 & US-8 \\
\hline & Suffolk & July & 2 & 2 & US-8 \\
\hline & Tioga & August & 4 & 4 & US-8 \\
\hline & Tompkins & October & 1 & 1 & US-8 \\
\hline & Wayne & August & 2 & 2 & US-8 \\
\hline & \multirow[t]{3}{*}{ Wyoming } & August & 1 & 1 & US-8 \\
\hline & & September & 1 & 1 & US-8 \\
\hline & & October & 1 & 1 & US-8 \\
\hline \multicolumn{2}{|c|}{ Isolates from tomato } & & 10 & 16 & \\
\hline Alabama & Blount & October & 1 & 1 & US-17 \\
\hline California & San Luis Obispo & September & 1 & 4 & US-16 \\
\hline Florida & Lee & December & 1 & 4 & US-17 \\
\hline New Jersey & Gloucester & September & 1 & 1 & US-17 \\
\hline \multirow[t]{6}{*}{ New York } & Chautauqua & October & 1 & 1 & US-17 \\
\hline & Clinton & September & 1 & 1 & US-8 \\
\hline & Ontario & September & 1 & 1 & US-8 \\
\hline & Orange & August & 1 & 1 & US-17 \\
\hline & Schenectady & August & 1 & 1 & US-1 \\
\hline & Tioga & September & 1 & 1 & US-8 \\
\hline
\end{tabular}

${ }^{a}$ For 36 isolates, multilocus genotype was predicted based on glucose-6phosphate isomerase genotype alone.

\section{DISCUSSION}

The devastating late blight epidemics in the United States during 1994 through 1996 were caused primarily by the US- 8 genotype of $P$. infestans. Based on our experiences through 1993, this was unexpected. US-7 was the most commonly detected genotype during 1993 and occurred throughout the country (23). It infected tomato in addition to potato (24), which we thought might give it a selective advantage. However, although US-7 caused some epidemics on tomato, primarily in the southeastern states during 1994, it was a relatively minor component of the population that year. This continued during 1995, and, by 1996, US-7 was not detected at all. In its place, a new genotype, US-17, began to appear on tomato.

By 1994, the old US-1 clonal lineage of $P$. infestans was almost totally replaced in the United States by new genotypes from Mexico. Although US-1 still occurs at a low frequency, it is no longer the major component of the U.S. population. The almost total replacement of US-1 occurred within 3 years after the new genotypes (US-7 and US-8) were first detected. Rapid replacement of US- 1 by US- 8 also has been documented locally in Wisconsin (31), the Columbia Basin of Oregon and Washington (33), and in central and eastern Canada (Z. K. Punja, unpublished data). Similar rapid replacements of US-1 have been documented in Europe (3, 9,10,13,36-38), Asia (28), and South America (11). However, the genotypes causing the replacements were different in each location. So far, the Gpi 111 allele (characteristic of the US-7 and US-8 genotypes) has not been found outside North America $(16,18)$. Conversely, genotypes characteristic of the European, South American, and Asian migrations have not been detected within North America. Thus, there is still potential for additional migrations that could spread damaging genotypes to new locations.

A rather disturbing result is that it was not always possible to predict which genotypes would be present from 1 year to the next. US-8 was a relatively minor component of the 1993 collections, found in less than $10 \%$ of the isolates analyzed and only in those from Maine. However, it predominated during 1994 and made up $77 \%$ of all isolates tested. After 1994, US-8 occurred throughout the United States, and no more major changes were noticed.

Inability to predict genotypes from year to year was particularly evident in New York during 1993 and 1994. US-7 was the only genotype detected in New York during 1993 and was distributed throughout the state (23). However, during 1994, US-7 was found only in one home garden, and instead, US-8 was found throughout the state. It is probable that in situ survival is low, so seed tuber infections are much more important. In addition, US-8 appears to have much greater pathogenic fitness than US-7 on potato $(27,29$, 30 ), which may have played a role in its rapid increase. We know that seed tubers planted in New York during 1994 were infected with US-8 (Table 2), and these must have provided the inoculum,

TABLE 6. Changes in frequency of the four most common genotypes of Phytophthora infestans detected in samples analyzed from the United States and Canada during 1979 to $1996^{\mathrm{a}}$

\begin{tabular}{lccccccc}
\hline & \multicolumn{6}{c}{ Frequency of detection (\%) during } \\
\cline { 2 - 8 } Genotype & $1979-1987^{\mathrm{b}}$ & $1987-1991^{\mathrm{c}}$ & $1992^{\mathrm{d}}$ & $1993^{\mathrm{e}}$ & $1994^{\mathrm{f}}$ & $1995^{\mathrm{g}}$ & $1996^{\mathrm{h}}$ \\
\hline US-1 & 65 & 19 & 30 & 21 & 8 & 3 & 8 \\
US-6 & 8 & 79 & 12 & 8 & 1 & $\ldots$ & $\ldots$ \\
US-7 & $\ldots$ & $\ldots$ & 34 & 48 & 6 & 43 & $\ldots$ \\
US-8 & $\ldots$ & $\ldots$ & 21 & 8 & 77 & 48 & 69 \\
\hline
\end{tabular}

a Based on a total sample of 1,112 isolates.

b $N=26$. Data for 1979 through the first half of 1987 are from Goodwin et al. (17).

c $N=146$. Data for the second half of 1987 through 1991 are from Goodwin et al. (17).

${ }^{\mathrm{d}} N=203$. Data from Goodwin et al. (23).

e $N=290$. Data from Goodwin et al. (23) and this study.

f $N=330$. This study.

g $N=65$. This study.

${ }^{\mathrm{h}} N=52$. This study. 
because there was no evidence for US- 8 from the previous year. This again underscores the importance of planting disease-free seed.

Distribution of $P$. infestans in seed tubers also was demonstrated in Florida. Seed tubers shipped into Florida from Maine and North Dakota during January 1993 were infected with US-1, and US-1 was the only genotype isolated from the field later that year (23). Seed shipped into Florida from Maine during late 1993 contained US-8, which was the only genotype identified in southern Florida during 1994. Thus, genotypes in seed gave a much better prediction of genotypes in the field from 1993 to 1994 than did the geno-
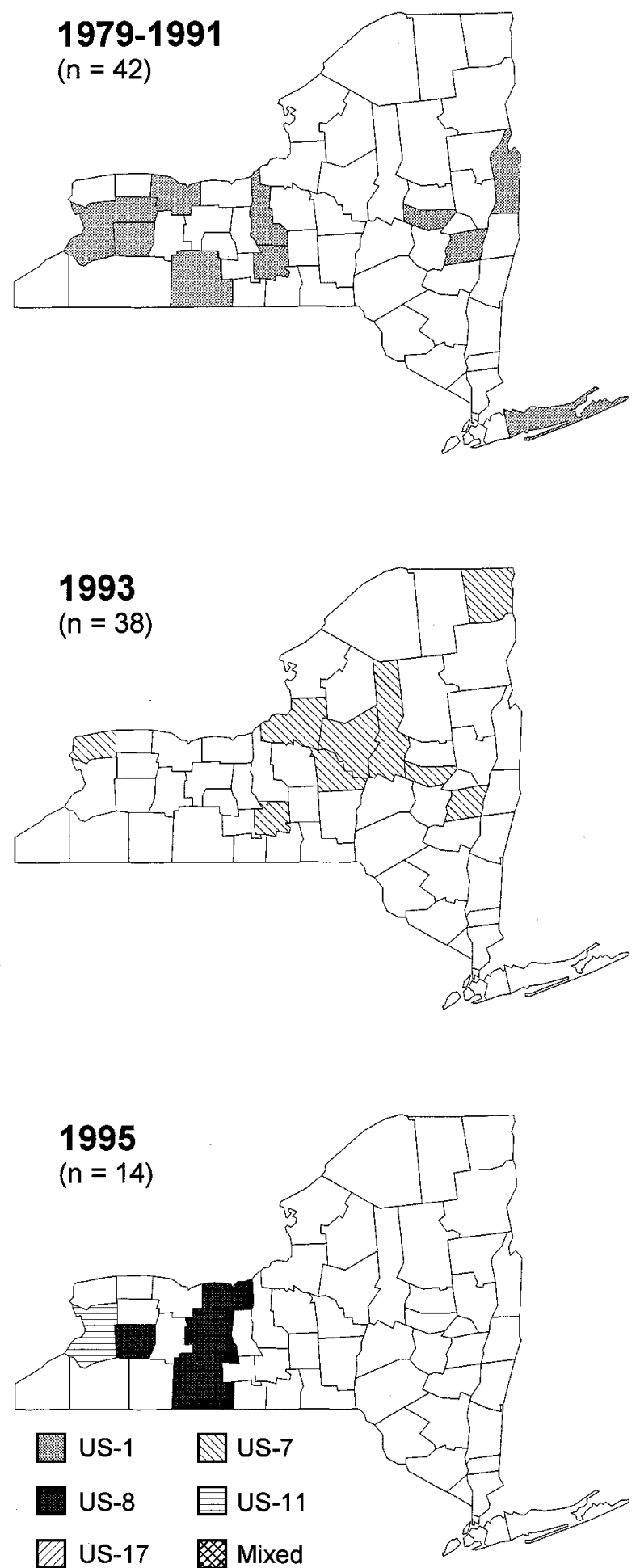

types that were present in the field the previous year. The only exception was US-1, which evidently was prevented from causing epidemics from seed tubers by early applications of metalaxyl.

These analyses confirmed that metalaxyl sensitivity and genotype still are correlated at least for the US-1, US-7, and US-8 genotypes. All US-1 isolates tested so far from the United States have been sensitive $(25,31,33)$, and this continued during 1994. Similarly, all US-7 and US-8 isolates still are resistant. The two US-6 isolates tested from Texas were highly sensitive. This confirms the polymorphism for metalaxyl sensitivity within the US-6
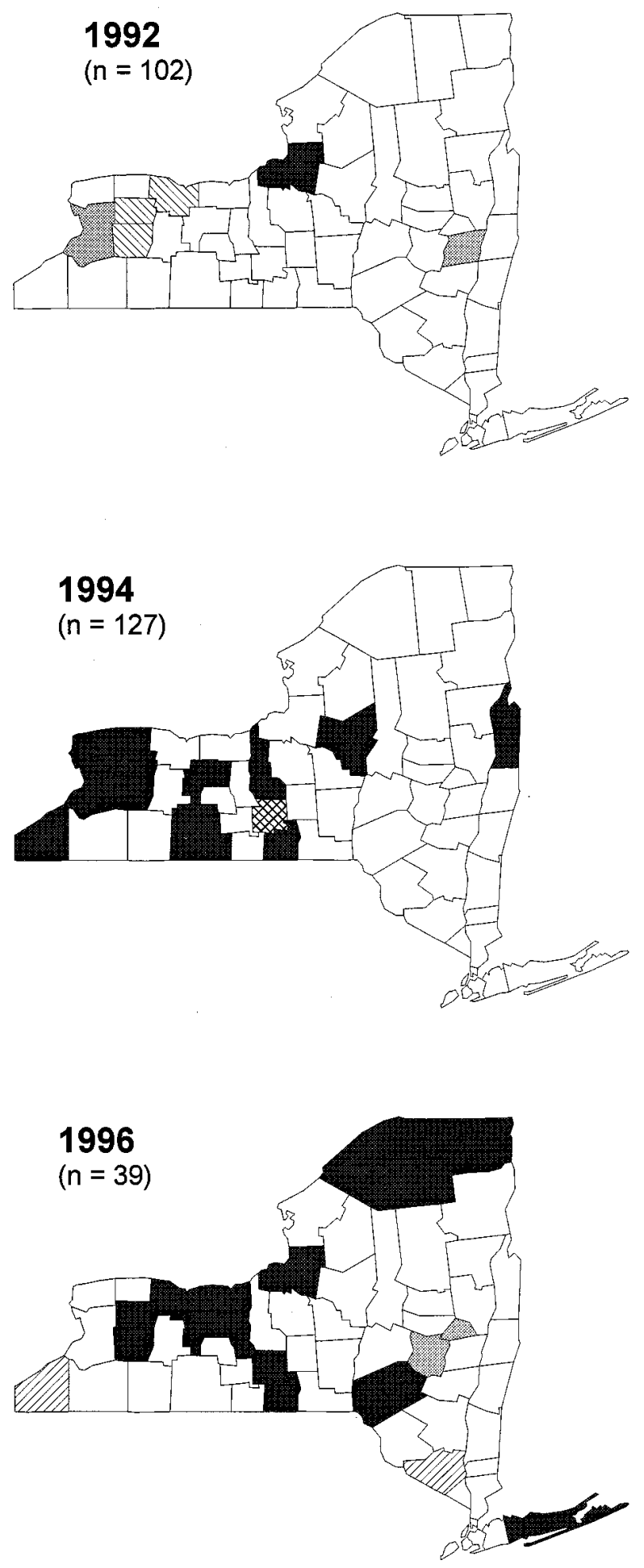

Fig. 3. Changes in collection locations of genotypes of Phytophthora infestans in New York by county among 362 isolates analyzed during 1979 through 1996. Sample sizes are in parentheses. Genotypes are as indicated in Table 1. "Mixed" refers to more than one genotype in the same county during 1 year. This only occurred during 1994, when the US-7, US-8, US-12, and US-13 genotypes were found in Tompkins County. 
clonal lineage noted previously (25). US-17 appears to be a new resistant genotype, because all eight isolates tested from four different states were highly resistant.

The floating leaf-disc assay eliminated some of the variance seen in the amended-agar assay and is recommended for all future studies. The floating leaf-disc results also may reflect results in the field more accurately. US-8 grows significantly less than US-7 on metalaxyl-amended agar (25). However, both US-7 and US-8 grow at virtually $100 \%$ of the control on floating leaf-disc assays and apparently are unaffected by metalaxyl in the field (25). Therefore, the floating leaf-disc results may provide a better prediction of response to metalaxyl in growers' fields.

During 1994 to 1996 in the United States, there still was only limited evidence for sexual recombination of $P$. infestans, even though both mating types have been widely distributed since 1992 $(5,23)$. This probably is because both mating types seldom were

TABLE 7. Metalaxyl sensitivities of isolates of Phytophthora infestans and $P$. capsici by genotype

\begin{tabular}{|c|c|c|c|c|}
\hline \multirow[b]{2}{*}{ Genotype } & \multirow[b]{2}{*}{ Isolate } & \multicolumn{2}{|c|}{ Percent of control $^{\mathrm{a}}$} & \multirow[b]{2}{*}{ Result } \\
\hline & & $5 \mu \mathrm{g} / \mathrm{ml}$ & $100 \mu \mathrm{g} / \mathrm{ml}$ & \\
\hline \multicolumn{5}{|c|}{ Amended-agar assays } \\
\hline \multirow[t]{3}{*}{ US-1 } & $151 \mathrm{MI}$ & 1 & 0 & Sensitive \\
\hline & NC-364 & 12 & 9 & Sensitive \\
\hline & NC-367 & 11 & 8 & Sensitive \\
\hline \multirow[t]{2}{*}{ US-6 } & TX $4-1^{b}$ & 3 & 3 & Sensitive \\
\hline & TX $4-3^{\mathrm{b}}$ & 3 & 3 & Sensitive \\
\hline \multirow[t]{6}{*}{ US-7 } & TX 3-4 & 104 & 49 & Resistant \\
\hline & TX $3-8^{\mathrm{b}}$ & 94 & 65 & Resistant \\
\hline & FL 318-2 & 71 & 61 & Resistant \\
\hline & FL 319-5 & 91 & 54 & Resistant \\
\hline & SC-1 & 106 & 96 & Resistant \\
\hline & SC-4 & 103 & 105 & Resistant \\
\hline \multirow{6}{*}{ US-8 } & GA-320 & 83 & 56 & Resistant \\
\hline & NC-P-4 & 105 & 60 & Resistant \\
\hline & NC-P-5 & 83 & 41 & Resistant \\
\hline & NC-P-6 & 75 & 58 & Resistant \\
\hline & NC-Pamlico-1 & 83 & 38 & Resistant \\
\hline & 146 Erie PA & 64 & 33 & Resistant \\
\hline US-11 & US94-0478 & $\ldots{ }^{c}$ & 63 & Resistant \\
\hline US-12 & US94-0494 & $\ldots$ & 60 & Resistant \\
\hline US-13 & Fleming, fruit 1 & $\ldots$ & 77 & Resistant \\
\hline US-14 & US94-0502 & $\ldots$ & 53 & Resistant \\
\hline US-16 & US94-0298 & $\ldots$ & 75 & Resistant \\
\hline \multirow[t]{8}{*}{ US-17 } & $96-444$ & $\ldots$ & 100 & Resistant \\
\hline & $96-505$ & $\ldots$ & 107 & Resistant \\
\hline & $96-543$ & $\ldots$ & 103 & Resistant \\
\hline & $96-550$ & $\ldots$ & 105 & Resistant \\
\hline & US97-0001 & $\ldots$ & 105 & Resistant \\
\hline & US97-0002 & $\ldots$ & 105 & Resistant \\
\hline & US97-0003 & $\ldots$ & 105 & Resistant \\
\hline & US97-0004 & $\ldots$ & 105 & Resistant \\
\hline \multicolumn{5}{|c|}{ Floating leaf-disc assays ( $5 \mu \mathrm{g} / \mathrm{ml}$ only) } \\
\hline \multirow[t]{6}{*}{ US-1 } & \#309 ND seed & 0 & $\ldots$ & Sensitive \\
\hline & \#310 ND seed & 0 & $\ldots$ & Sensitive \\
\hline & \#313 ND seed & 0 & $\ldots$ & Sensitive \\
\hline & \#314 ND seed & 0 & $\ldots$ & Sensitive \\
\hline & \#315 ND seed & 0 & $\ldots$ & Sensitive \\
\hline & \#317 ND seed & 0 & $\ldots$ & Sensitive \\
\hline US-7 & FL $318-2^{\mathrm{d}}$ & 95 & $\ldots$ & Resistant \\
\hline \multirow[t]{4}{*}{ US-8 } & 14263-2 ME & 101 & $\ldots$ & Resistant \\
\hline & 14263-3 ME & 98 & $\ldots$ & Resistant \\
\hline & 14263-4 ME & 103 & $\ldots$ & Resistant \\
\hline & \#311 Maine seed & 99 & $\ldots$ & Resistant \\
\hline \multicolumn{5}{|c|}{ Phytophthora capsici agar assays } \\
\hline CAP-1 & CA 2 & 3 & 1 & Sensitive \\
\hline CAP-1 & CA 3 & 1 & 0 & Sensitive \\
\hline
\end{tabular}

${ }^{a}$ Growth of an isolate on media containing 5 or $100 \mu \mathrm{g}$ of metalaxyl per ml relative to the unamended control. The percent leaf disc area covered by sporulation relative to the unamended control was measured for the floating leaf-disc assay.

b Texas isolates collected during 1993, but analyzed during 1994 .

${ }^{\mathrm{c}}$ Not tested.

d Also tested with the amended-agar assay. found together in the same field. Goodwin et al. (23) found both mating types together only in one field in Florida among more than 100 fields from which multiple isolates were obtained during 1992 and 1993. Deahl et al. (5) analyzed 184 U.S. isolates collected during 1991 through 1993 and found both mating types together only occasionally in Florida (probably from the same field sampled by Goodwin et al. [23]) and Texas. The Texas isolates were analyzed in the current study and were all US-6 or US-7. Thus, in Florida and Texas, both mating types probably were introduced too recently for the products of sexual recombination to become detectable. Both mating types have been found together more often in British Columbia (2), where the first probable evidence for sexual recombination was found during 1992 (23). Both mating types also were found together in seven fields in New Brunswick during 1994 (2), but that is probably when A2 was first introduced, so opportunities for sexual recombination were minimal. Increased sampling in Florida, Texas, and New Brunswick is needed to determine whether coexistence of both mating types led to additional instances of sexual recombination.

Opportunities for sexual recombination remained limited during 1994 through 1996. In our samples, both mating types were found together only in one field in New York, one county in California, and one field in Texas among 94 U.S. fields with multiple samples. Furthermore, the mating types usually were separated geographically, even when they occurred in the same state. For example, during 1994 in Michigan, A1 isolates were found only in Presque Isle County at the northern tip of the southern peninsula, while A2 isolates were limited to the central part of the state. Similarly, during 1994 in North Carolina, A1 isolates were found only in one eastern county from which no A2 isolates were obtained. During 1996 in New York, A1 isolates were found only in one western and three eastern counties, while US-8 (A2) was found in 14 other counties throughout the state. Although the limited sampling obviously underestimates the true range of both mating types, it does indicate that, in the United States, opportunities for sexual recombination of $P$. infestans remain limited 4 years after A2 became widespread.

Opportunities for sexual reproduction also probably were limited by the high sensitivity of the US-1 clonal lineage to metalaxyl. US-1 was detected in shipments of seed tubers from North Dakota that were planted subsequently in New York (and presumably other states). Many growers who planted infected seed sprayed with metalaxyl in an attempt to eliminate US-1. Evidently, this strategy was successful. All US-1 isolates tested were highly sensitive, and this probably explains the absence of US-1 from metalaxyl-treated fields. Many of these fields did contain US-8, probably introduced by wind-borne inoculum from nearby fields, so sexual reproduction could have occurred had US-1 been present. Thus, use of metalaxyl may have provided an unseen benefit even when it did not halt an epidemic.

However, some potential recombinant genotypes were rarely detected during 1994 through 1996. The most common of these was the US-11 genotype, which was A1 mating type, Gpi 100/100/111, Pep 100/100, and was found in California, New York, and Washington. This genotype also was reported in the Columbia Basin of Oregon and Washington during 1993 (33). It could have originated by recombination between US-6 (A1) and US-7 or US-8 (A2). The presence of DNA fingerprint band 6 in US-11 excludes US- 1 as a likely A1 parent, because this band also is absent from both US-7 and US-8. Both US-8 and US-11 apparently are trisomic (have three copies) for the chromosome containing the Gpi locus, and crosses involving US-8 yield a high frequency of trisomic progeny in the laboratory (22). Thus, recombination between US-6 and US-8 may be the most likely origin of the Gpi 100/100/111 genotype of US-11.

Four other potential recombinant genotypes were found in fields of tomato. US-12 was found in Maclean, NY; US-13 in Dryden, NY; US-16 in California; and US-17 in Alabama, Florida, New Jersey, and New York (Table 8). US-13 could have been generated by hybridization between US-1 or US-6 (A1) and US-7 
or US-8 (A2). This also could have been the origin of the CA- 8 genotype from potato in British Columbia. For US-17, the parents were most likely US-6 and US-8, to have both the Gpi 122 allele and DNA fingerprint band 18. US-16 could have originated by a cross between US-6 and US-7 or US-8 (not US-1). US-12 could not have originated by hybridization between US-1 and US-8, as neither has DNA fingerprint band 18. However, it could have originated by a cross between US-1 and US-7, or US-6 by US-7 or US-8. In fact, all of these genotypes could have arisen by hybridization between US-6 and US-8. Isolates with the same mating type and

TABLE 8. Summary of genotypes of Phytophthora infestans identified in the United States and Canada during 1979 to 1996

\begin{tabular}{|c|c|c|c|c|c|c|}
\hline \multirow{2}{*}{ Genotype $^{a}$} & \multirow{2}{*}{$\begin{array}{l}\text { Mating } \\
\text { type }\end{array}$} & \multicolumn{2}{|c|}{ Allozyme genotype } & \multirow[b]{2}{*}{ RG57 fingerprint $^{\mathrm{d}}$} & \multirow{2}{*}{$\begin{array}{l}\text { Metalaxyl } \\
\text { sensitivity }\end{array}$} & \multirow[b]{2}{*}{ Comments } \\
\hline & & $G p i^{\mathrm{b}}$ & $P e p^{\mathrm{c}}$ & & & \\
\hline US-1 & A1 & $86 / 100$ & $92 / 100$ & 1011101011001101000110011 & $\mathrm{~S}$ & Old established genotype possibly present since the $1840 \mathrm{~s}$. \\
\hline US-1.1 & A1 & $86 / 100$ & $100 / 100$ & 1011101011001101000110011 & $\ldots$ & One isolate from New York during 1979, and one from New Brunswick during 1980. \\
\hline US-1.2 & A1 & $86 / 100$ & $92 / 100$ & 1011101010001101000110011 & $\ldots$ & $\begin{array}{l}\text { Two isolates from Wisconsin during 1982, and one isolate during } 1980 \text { (location } \\
\text { unknown). }\end{array}$ \\
\hline US-1.3 & A1 & $86 / 100$ & $92 / 100$ & 1011101001001101000110011 & $\ldots$ & One isolate from Wisconsin during 1982. \\
\hline US-1.4 & A1 & $86 / 100$ & $100 / 100$ & 1011101010001101000110011 & & One isolate from North Carolina during 1985. \\
\hline US-1.5 & A1 & $86 / 100$ & $92 / 100$ & 1011101011001101010110011 & $\ldots$ & One isolate from Prince Edward Island during 1992. \\
\hline US-1.6 & A1 & $86 / 100$ & $92 / 100$ & 1011101011001101000111011 & $\ldots$ & One isolate from Peru during 1984. \\
\hline US-1.7 & A1 & $100 / 100$ & $92 / 100$ & 1011101011001101000110011 & $\ldots$ & One isolate from Brazil during 1987. \\
\hline US-1.8 & A1 & $86 / 100$ & $92 / 100$ & 1011100011001101000110011 & $\ldots$ & One isolate from Poland during 1988. \\
\hline US-2 & A1 & $86 / 100$ & $92 / 100$ & 1011101001001101011110011 & $\ldots$ & One isolate, year and location of isolation not known. \\
\hline US-3 & A1 & $86 / 100$ & $92 / 100$ & 1011100000001101000110011 & $\ldots$ & One isolate from 1983, location unknown. \\
\hline US-4 & A1 & $100 / 100$ & $92 / 92$ & 1011101001001101100110011 & $\ldots$ & One isolate from California during 1980. \\
\hline US-5 & A1 & $100 / 100$ & $92 / 100$ & 1011101001001101011110011 & $\mathrm{~S}$ & $\begin{array}{l}\text { Two isolates from Maine during } 1987 \text {, and one isolate during } 1987 \text {, location un- } \\
\text { known. Probably the same clonal lineage as US- } 2 \text {. }\end{array}$ \\
\hline US-6 & A1 & $100 / 100$ & $92 / 100$ & 1011111001001100010110011 & $\mathrm{R}$ or $\mathrm{S}$ & $\begin{array}{l}\text { Possibly introduced into California during 1979; since found throughout the United } \\
\text { States and western Canada. Mostly on tomato, potato occasionally. }\end{array}$ \\
\hline US-6.1 & A1 & $100 / 100$ & $92 / 92$ & 1011111001001100010110011 & $\ldots$ & One isolate from California during 1987. \\
\hline US-6.2 & A1 & $100 / 100$ & $92 / 100$ & 1011101001001100010110011 & I & One isolate from western Washington during 1990. \\
\hline US-6.3 & A1 & $100 / 100$ & $92 / 100$ & 1011111001011100010110011 & $\mathrm{R}$ & One isolate from British Columbia during 1991. \\
\hline US-6.4 & A1 & $100 / 100$ & $100 / 100$ & 1011011001001100010110011 & $\mathrm{R}$ & One isolate from British Columbia during 1991. \\
\hline US-6.5 & A1 & $100 / 100$ & $92 / 100$ & 1011111001001100010010011 & $\mathrm{R}$ & $\begin{array}{l}\text { Single isolates from eastern Washington and British Columbia during } 1991 \text { and } \\
\text { 1993, respectively. }\end{array}$ \\
\hline US-7 & $\mathrm{A} 2$ & $100 / 111$ & $100 / 100$ & 1001100001001101010110011 & $\mathrm{R}$ & $\begin{array}{l}\text { Recent immigrant from northwestern Mexico found throughout the United States and } \\
\text { western Canada. Mostly on tomato, potato occasionally. }\end{array}$ \\
\hline US-8 & $\mathrm{A} 2$ & $100 / 111 / 122$ & $100 / 100$ & 1001100001001101000110111 & $\mathrm{R}$ & $\begin{array}{l}\text { Recent immigrant from northwestern Mexico now found throughout the United } \\
\text { States and western Canada. Mostly on potato, tomato occasionally. }\end{array}$ \\
\hline US-9 & A1 & $100 / 100$ & $83 / 100$ & $\ldots$ & $\mathrm{R}$ & $\begin{array}{l}\text { One isolate from Idaho during 1993, on greenhouse tomato. Possibly introduced } \\
\text { from Europe. }\end{array}$ \\
\hline US-10 & $\mathrm{A} 2$ & $111 / 122$ & $100 / 100$ & $\ldots$ & $\mathrm{S}$ & $\begin{array}{l}\text { One isolate from Wisconsin during 1993. Probably a sexual recombinant or recent } \\
\text { immigrant from northwestern Mexico. }\end{array}$ \\
\hline US-11 & A1 & $100 / 100 / 111$ & $100 / 100$ & 1010111001001101010110011 & $\mathrm{R}$ & $\begin{array}{l}\text { Probable sexual recombinant; has two copies of Gpi } 100 \text { allele. Found in western } \\
\text { Washington during 1994, and California and New York during } 1995 .\end{array}$ \\
\hline US-12 & A1 & $100 / 111$ & $92 / 100$ & 1000100001001100010110011 & $\mathrm{R}$ & $\begin{array}{l}\text { Probable sexual recombinant. Found in one field of tomato in Maclean, NY, during } \\
1994 .\end{array}$ \\
\hline US-13 & $\mathrm{A} 2$ & $100 / 100$ & $100 / 100$ & $\ldots$ & $\mathrm{R}$ & $\begin{array}{l}\text { Possible sexual recombinant; also could have been imported from northwestern } \\
\text { Mexico. Found in one field of tomato in Dryden, NY, during } 1994 .\end{array}$ \\
\hline US-14 & $\mathrm{A} 2$ & $100 / 122$ & $100 / 100$ & 1000100001001101000110111 & $\mathrm{R}$ & $\begin{array}{l}\text { Probable clonal derivative of US-8 (by loss of Gpi } 111 \text { allele). Found in one potato } \\
\text { field in Steuben County, NY, during 1994. Also could be called US-8.1. }\end{array}$ \\
\hline US-15 & A2 & $100 / 100$ & $92 / 100$ & $\cdots$ & $\cdots$ & $\begin{array}{l}\text { Three isolates from tomato in Pennsylvania during } 1994 \text { (S. Kim, personal commu- } \\
\text { nication). }\end{array}$ \\
\hline US-16 & A1 & $100 / 111$ & $100 / 100$ & 1000110001001101010110011 & $\mathrm{R}$ & $\begin{array}{l}\text { Probable sexual recombinant between US-6 and US-7 or US-8. Isolated in Oregon } \\
\text { during 1994, and from tomato in California during } 1996 .\end{array}$ \\
\hline US-17 & A1 & $100 / 122$ & $100 / 100$ & 1010001000001101010110011 & $\mathrm{R}$ & $\begin{array}{l}\text { Probable sexual recombinant between US-6 and US-8. Isolated from tomato in Ala- } \\
\text { bama, Florida, New Jersey, and New York during } 1996 .\end{array}$ \\
\hline $\mathrm{CDA}-1^{\mathrm{f}}$ & A1 & $86 / 100$ & $92 / 100$ & 11111010110011010011100111 & $\cdots$ & $\begin{array}{l}\text { One isolate from New Brunswick during } 1980 \text {. The fingerprint for this isolate also } \\
\text { contains the rare band 11a. }\end{array}$ \\
\hline $\mathrm{CDA}-2^{\mathrm{f}}$ & A1 & $100 / 100$ & $100 / 100$ & 1011001000001100001110011 & $\mathrm{~S}$ & One isolate from British Columbia during 1991. \\
\hline CA-2.1 & A1 & $100 / 100$ & $100 / 100$ & 1011001000001100001111011 & $\ldots$ & $\begin{array}{l}\text { One isolate from British Columbia during 1991. Probably the same clonal lineage as } \\
\text { CDA-2. }\end{array}$ \\
\hline $\mathrm{CDA}-3^{\mathrm{f}}$ & $\mathrm{A} 2$ & $86 / 100$ & $100 / 100$ & 1111101001001001100110011 & $\ldots$ & Two isolates from British Columbia during 1991. \\
\hline $\mathrm{BC}-1^{\mathrm{f}}$ & $\mathrm{A} 2$ & $100 / 111$ & $100 / 100$ & 1000000001001101000110011 & I & $\begin{array}{l}\text { Possible sexual recombinant or recent immigrant. Isolated in British Columbia dur- } \\
\text { ing } 1992 \text { and } 1993 .\end{array}$ \\
\hline $\mathrm{BC}-2^{\mathrm{f}}$ & $\mathrm{A} 2$ & $100 / 100$ & $100 / 100$ & 1000110000001101000110011 & $\mathrm{~S}$ & Probable sexual recombinant. One isolate from British Columbia during 1992. \\
\hline $\mathrm{BC}-3^{\mathrm{f}}$ & A2 & $100 / 100$ & $100 / 100$ & 1010001001001100010110011 & $\mathrm{~S}$ & Probable sexual recombinant. One isolate from British Columbia during 1992. \\
\hline $\mathrm{BC}-4^{\mathrm{f}}$ & A2 & $100 / 100$ & $100 / 100$ & 1001000000001100010110011 & $\mathrm{~S}$ & Probable sexual recombinant. One isolate from British Columbia during 1992. \\
\hline CA-8 & A1 & $100 / 111 / 111$ & $100 / 100$ & $\ldots$ & $\ldots$ & Probable sexual recombinant. Two isolates from British Columbia during 1993. \\
\hline
\end{tabular}

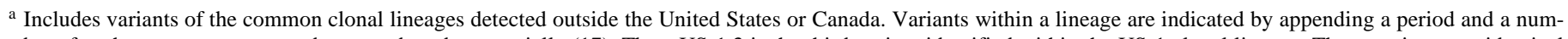

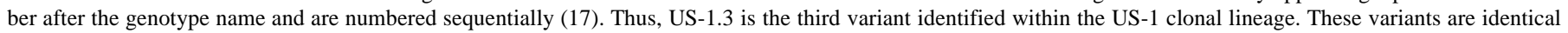
to the "parent" clone except for one or two changes at allozyme or DNA fingerprint loci. They are assumed to have arisen from asexual (somatic) variation within lineages.

b Glucose-6-phosphate isomerase.

c Peptidase.

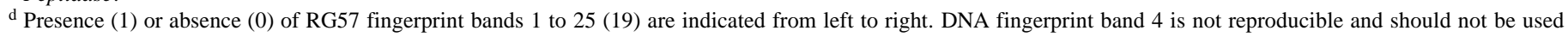
for genotype identification. ... = Not determined.

e $\mathrm{S}=$ sensitive, $\mathrm{R}=$ resistant, $\mathrm{I}=$ intermediate, and $\ldots=$ not determined.

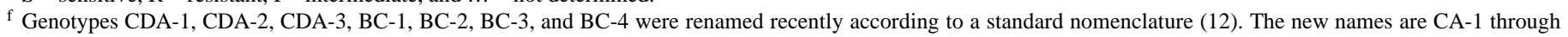
CA-7, respectively. 
Gpi genotype as US-11 through US-14 also were reported in the Pacific Northwest during 1993 (33), along with two additional genotypes not detected in our samples. Additional sampling probably will reveal more genotypes. Even so, potential recombinant genotypes made up only a small proportion of the total sample, compared with some newly sexual populations in Europe in which nearly $100 \%$ of the isolates tested were recombinant $(10,38)$.

One other new genotype, US-14, was from a potato field in southern New York that also contained US-8. US-14 had the same DNA fingerprint as US-8 and almost certainly arose as a somatic variant of US-8 by loss of the Gpi 111 allele.

In addition to sexual recombination, another potential source of new genotypes is continued migration from Mexico or other areas. Isolates identical to US-10 (from Wisconsin during 1993 [23]), US-13, and US-14 for mating type and dilocus allozyme genotype were found in northwestern Mexico during 1993 (S. B. Goodwin and W. E. Fry, unpublished data), and together accounted for almost $57 \%$ of the 109 isolates sampled that year. However, US-11 and US-12 so far have not been found in Mexico (22; S. B. Goodwin and W. E. Fry, unpublished data). Thus, although migration remains a possibility for some of the new genotypes, it seems remote for others. The most likely explanation is that at least some of the rare, new genotypes originated by sexual recombination within the United States. This also could be the origin of the US-15 genotype identified by S. H. Kim (personal communication) in Pennsylvania during 1994 (Table 8) and of the two additional genotypes identified recently in the Pacific Northwest (33). Other genotypes that probably originated by in situ sexual recombination were identified in British Columbia during 1992 (23) and 1993 (Table 8). Future monitoring is required to determine whether sexually reproducing populations of $P$. infestans now have become established in the United States and Canada, and how they might affect late blight epidemiology.

Isolates of two other species of Phytophthora that are found commonly on potato or tomato were easy to distinguish from $P$. infestans and from each other on the basis of Gpi genotype alone. All four isolates of $P$. capsici tested had the same genotype at the Gpi (106/106) and Pep (94/94) loci. This genotype probably is the same as genotype CAP-1 of Oudemans and Coffey (35), and we have retained their appellation. All 21 isolates of $P$. erythroseptica were Gpi 91/91; we could not resolve Pep bands for this species. Because each species had a distinct genotype, cellulose-acetate electrophoresis provides a fast, easy method for identification of $P$. erythroseptica and $P$. capsici, as well as genotypes of $P$. infestans (21). It is interesting that the two isolates of $P$. capsici tested were highly sensitive to metalaxyl, because they came from a field that had been sprayed and the grower thought they might be resistant. Thus, in $P$. capsici, loss of effectiveness of metalaxyl may be due to other factors besides resistance.

The mechanisms for the rapid spread of the US-8 genotype of $P$. infestans in the United States and Canada during 1994 are partially known. US-8 evidently became established in seed-producing areas of Maine and possibly other states during 1993 (23) and probably was distributed in infected seed during 1994. When both genotypes were in infected seed, sometimes in adjacent fields, the resistance of US-8 to metalaxyl probably explains its advantage compared with US-1. However, the most likely explanation may be that US-8 simply has higher pathogenic fitness on potato (both foliage and tubers) than the other common genotypes (27,29). US-8 also infected hairy nightshade (as does US-1 [23]), which may provide a bridge from field to field. Isolates of $P$. infestans now have been obtained from hairy nightshade (S. sarrachoides) in California (39), Wisconsin (23), Washington (7), and New York (this study). Clearly, this weed should be eliminated as much as possible from potato and tomato production areas.

The new genotypes obviously are much more difficult to control; a recent study showed that more frequent applications of fungicide will be required to achieve the same level of disease suppres- sion for US-8 compared with US-1 (27). Models for predicting late blight epidemics (e.g., Blitecast) should be modified, or at least verified, against the new genotypes. The role and effect of oospore inoculum on late blight epidemics is not known. Epidemics could occur more often, earlier in the season, and with greater severity. Continued monitoring of the pathogen may be warranted for advance notice of future changes. The next few years could be very difficult until improved methods of disease management are developed to combat the new genotypes.

\section{ACKNOWLEDGMENTS}

Supported, in part, by USDA-ARS Special Grants 1975-21220-061-01S, 58-3650-5-147, and 58-1275-6043. We thank the huge number of cooperators throughout the United States and Canada who supplied us with infected tissue or isolates. Although too numerous to acknowledge individually, this study could not have been completed without their help. We hope that the publication of this paper in some small way will diminish our debt to those who assisted us. We thank K. Doucett, B. Fry, J.-H. Ham, D. Karasevicz, S. Mack, H. Mayton, J.-H. Ok, and R. Schneider for technical assistance.

\section{LITERATURE CITED}

1. Caten, C. E., and Jinks, J. L. 1968. Spontaneous variability of single isolates of Phytophthora infestans. I. Cultural variation. Can. J. Bot. 46: 329-348.

2. Chycoski, C. I., and Punja, Z. K. 1996. Characteristics of populations of Phytophthora infestans from potato in British Columbia and other regions of Canada during 1993 to 1995. Plant Dis. 80:579-589.

3. Day, J. P., and Shattock, R. C. 1997. Aggressiveness and other factors relating to displacement of populations of Phytophthora infestans in England and Wales. Eur. J. Plant Pathol. 103:379-391.

4. Deahl, K. L., DeMuth, S. P., Pelter, G., and Ormrod, D. J. 1993. First report of resistance of Phytophthora infestans to metalaxyl in eastern Washington and southwestern British Columbia. Plant Dis. 77:429.

5. Deahl, K. L., DeMuth, S. P., Sinden, S. L., and Rivera-Peña, A. 1995. Identification of mating types and metalaxyl resistance in North American populations of Phytophthora infestans. Am. Potato J. 72:35-49.

6. Deahl, K. L., Goth, R. W., Young, R., Sinden, S. L., and Gallegly, M. E. 1991. Occurrence of the $\mathrm{A}^{2}$ mating type of Phytophthora infestans in the United States and Canada. Am. Potato J. 68:717-725.

7. Deahl, K. L., and Inglis, D. A. 1995. Occurrence of metalaxyl-insensitive Phytophthora infestans on Solanum sarrachoides in northwestern Washington. Plant Dis. 79:540.

8. Deahl, K. L., Inglis, D. A., and DeMuth, S. P. 1993. Testing for resistance to metalaxyl in Phytophthora infestans isolates from northwestern Washington. Am. Potato J. 70:779-795.

9. Drenth, A., Goodwin, S. B., Fry, W. E., and Davidse, L. C. 1993. Genotypic diversity of Phytophthora infestans in the Netherlands revealed by DNA polymorphisms. Phytopathology 83:1087-1092.

10. Drenth, A., Tas, I. C. Q., and Govers, F. 1994. DNA fingerprinting uncovers a new sexually reproducing population of Phytophthora infestans in the Netherlands. Eur. J. Plant Pathol. 100:97-107.

11. Forbes, G. A., Escobar, X. C., Ayala, C. C., Revelo, J., Ordoñez, M. E., Fry, B. A., Doucett, K., and Fry, W. E. 1997. Population genetic structure of Phytophthora infestans in Ecuador. Phytopathology 87:375-380.

12. Forbes, G. A., Goodwin, S. B., Drenth, A., Oyarzun, P., Ordoñez, M. E., and Fry, W. E. 1998. A global marker database for Phytophthora infestans. Plant Dis. 82:811-818.

13. Fry, W. E., Drenth, A., Spielman, L. J., Mantel, B. C., Davidse, L. C., and Goodwin, S. B. 1991. Population genetic structure of Phytophthora infestans in the Netherlands. Phytopathology 81:1330-1336.

14. Fry, W. E., and Goodwin, S. B. 1995. Recent migrations of Phytophthora infestans. Pages 89-95 in: Phytophthora infestans 150. L. J. Dowley, E. Bannon, L. R. Cooke, T. Keane, and E. O'Sullivan, eds. Boole Press, Ltd., Dublin.

15. Fry, W. E., and Goodwin, S. B. 1997. Resurgence of the Irish potato famine fungus. BioScience 47:363-371.

16. Goodwin, S. B. 1997. The population genetics of Phytophthora. Phytopathology 87:462-473.

17. Goodwin, S. B., Cohen, B. A., Deahl, K. L., and Fry, W. E. 1994. Migration from northern Mexico as the probable cause of recent genetic changes in populations of Phytophthora infestans in the United States and Canada. Phytopathology 84:553-558.

18. Goodwin, S. B., Cohen, B. A., and Fry, W. E. 1994. Panglobal distribution of a single clonal lineage of the Irish potato famine fungus. Proc. 
Natl. Acad. Sci. U.S.A. 91:11591-11595.

19. Goodwin, S. B., Drenth, A., and Fry, W. E. 1992. Cloning and genetic analyses of two highly polymorphic, moderately repetitive nuclear DNAs from Phytophthora infestans. Curr. Genet. 22:107-115.

20. Goodwin, S. B., and McGrath, M. T. 1995. Insensitivity to metalaxyl among isolates of Phytophthora erythroseptica causing pink rot of potato in New York. Plant Dis. 79:967.

21. Goodwin, S. B., Schneider, R. E., and Fry, W. E. 1995. Use of celluloseacetate electrophoresis for rapid identification of allozyme genotypes of Phytophthora infestans. Plant Dis. 79:1181-1185.

22. Goodwin, S. B., Spielman, L. J., Matuszak, J. M., Bergeron, S. N., and Fry, W. E. 1992. Clonal diversity and genetic differentiation of Phytophthora infestans populations in northern and central Mexico. Phytopathology 82:955-961.

23. Goodwin, S. B., Sujkowski, L. S., Dyer, A. T., Fry, B. A., and Fry, W. E. 1995. Direct detection of gene flow and probable sexual reproduction of Phytophthora infestans in northern North America. Phytopathology 85:473-479.

24. Goodwin, S. B., Sujkowski, L. S., and Fry, W. E. 1995. Rapid evolution of pathogenicity within clonal lineages of the potato late blight disease fungus. Phytopathology 85:669-676.

25. Goodwin, S. B., Sujkowski, L. S., and Fry, W. E. 1996. Widespread distribution and probable origin of resistance to metalaxyl in clonal genotypes of Phytophthora infestans in the United States and western Canada. Phytopathology 86:793-800.

26. Johnson, D. A., Cummings, T. F., Hamm, P. B., Rowe, R. C., Miller, J. S., Thornton, R. E., Pelter, G. Q., and Sorensen, E. J. 1997. Potato late blight in the Columbia Basin: An economic analysis of the 1995 epidemic. Plant Dis. 81:103-106.

27. Kato, M., Mizubuti, E. S., Goodwin, S. B., and Fry, W. E. 1997. Sensitivity to protectant fungicides and pathogenic fitness of clonal lineages of Phytophthora infestans in the United States. Phytopathology 87:973-978.

28. Koh, Y. J., Goodwin, S. B., Dyer, A. T., Cohen, B. A., Ogoshi, A., Sato, N., and Fry, W. E. 1994. Migrations and displacements of Phytophthora infestans populations in East Asian countries. Phytopathology 84:922-927.
29. Lambert, D. H., and Currier, A. I. 1997. Differences in tuber rot development for North American clones of Phytophthora infestans. Am. Potato J. 74:39-43.

30. Legard, D. E., Lee, T. Y., and Fry, W. E. 1995. Pathogenic specialization in Phytophthora infestans: Aggressiveness on tomato. Phytopathology 85:1356-1361.

31. Marshall-Farrar, K. D., McGrath, M., James, R. V., and Stevenson, W. R. 1998. Characterization of Phytophthora infestans in Wisconsin from 1993 to 1995 . Plant Dis. 82:434-436.

32. Matuszak, J. M., Fernandez-Elquezabal, J., Gu, W. K., Villarreal-Gonzalez, M., and Fry, W. E. 1994. Sensitivity of Phytophthora infestans populations to metalaxyl in Mexico: Distribution and dynamics. Plant Dis. 78: 911-916.

33. Miller, J. S., Hamm, P. B., and Johnson, D. A. 1997. Characterization of the Phytophthora infestans population in the Columbia Basin of Oregon and Washington from 1992 to 1995. Phytopathology 87:656-660.

34. Miller, P. M. 1955. V-8 juice agar as a general-purpose medium for fungi and bacteria. Phytopathology 45:461-462.

35. Oudemans, P., and Coffey, M. D. 1991. A revised systematics of twelve papillate Phytophthora species based on isozyme analysis. Mycol. Res. 95:1025-1046.

36. Shattock, R. C., and Day, J. P. 1996. Migration and displacement; recombinants and relicts: 20 years in the life of potato late-blight (Phytophthora infestans). Pages 1129-1136 in: Proc. Brighton Crop Prot. Conf. Pests Dis. British Crop Protection Council, Farnham, Surrey, United Kingdom.

37. Spielman, L. J., Drenth, A., Davidse, L. C., Sujkowski, L. J., Gu, W. K., Tooley, P. W., and Fry, W. E. 1991. A second world-wide migration and population displacement of Phytophthora infestans? Plant Pathol. 40: 422-430.

38. Sujkowski, L. S., Goodwin, S. B., Dyer, A. T., and Fry, W. E. 1994. Increased genotypic diversity via migration and possible occurrence of sexual reproduction of Phytophthora infestans in Poland. Phytopathology 84:201-207.

39. Vartanian, V. G., and Endo, R. M. 1985. Overwintering hosts, compatibility types, and races of Phytophthora infestans on tomato in southern California. Plant Dis. 69:516-519. 